\title{
The Examination of Using Business Intelligence Systems by Enterprises in Hungary
}

\author{
Peter Sasvari \\ Institute of Business Sciences, Faculty of Economics \\ University of Miskolc \\ Miskolc-Egyetemvaros, Hungary
}

\begin{abstract}
Data are one of the key elements in corporate decision-making, without them, the decision-making process cannot be imagined. As a consequence, different analytical tools are needed that allow the efficient use of data, information and knowledge. These analytical tools are commonly called Business Intelligence systems that are introduced into the opeartion of enterprises to make access to business data easier, faster and broader in line with the needs of a given enterprise. Based on the findings of an empirical survey, this paper aims to give a deeper insight of the causes and purposes of using BI systems by Hungarian enterprises. It is revealed that such systems are mostly used for risk analysis, financial analysis, market analysis and controlling while their potential to make predictions is usually overlooked. One important conclusion of the paper is that the faster spread of BI systems would be facilitated by reducing costs, simpler parameter settings and a higher level of data protection.
\end{abstract}

\section{Keywords-Business Intelligence; Hungary; Enterprises}

\section{INTRODUCTION}

Nowadays a revolution is taking place in the field of information technology. The globalized and fast-paced business world together with a lot of other factors brings about a continuous increase in the volume of data [15]. Businesses have to discover the knowledge in the depths of overflowing data if they want to be successful. A fast and flexible response is an indispensable condition for a company's advancement. Enterprises should use huge amounts of data in a way that helps them to make profits sooner or later [5]. The significant amount of unstructured data is not sufficient to allow the company's management to make the most advantageous decisions in certain situations. As a first step, data must be converted into information and then into profitable knowledge, Knowledge through which the management can make the most profitable strategic decision for the organization. Thus, application of the business is essential to stay ahead of tools and technologies that are affected by these exploratory processes.

First, a brief review is given on the definition and concept of Business Intelligence systems, then the main elements and the advantages of using BI systems are presented. Based on an empirical research carried out in Hungary, the benefits of using such systems are demonstrated through the experience of Hungarian enterprises. Finally, some thought are given to the question of what factors could contribute to the faster penetration of BI systems.

\section{THE FIRST CONCEPTS OF BI}

In vain has become one of today's commonly used in an expression of BI, not a definition can be easy task. And a number of different conceptual approaches, a description can be found in the exploration of the topic. The literature on the concept of the creation of Howard Dresner name connects who in 1989 had defined BI systems as "in the broad category of software and solutions for gathering, consolidating, analysing and providing access to data in a way that lets enterprise users make better business decisions".[17]

Cser, Fajszi and Feher [13] further work detailed approach can discover the BI determination: "The business intelligence technologies, applications, methodologies, total process management and organizational units that are prepared and business decision-making process of the company support throughout the whole corporate data assets." This formulation breaks the components of BI, while highlighting the most important function of the decision aid. A term used by Gabor et al [1] says: "Business Intelligence solutions build on the achievements of the knowledge management, data warehousing, data mining and business analytics. With the help of key processes, identify data tracking, it becomes possible to improve; identify, monitor trends within the company, competitors and market performance." This document mainly focuses on using BI as practicable activities and processes. Loshin [4] offers another definition which states: "The necessary processes, technologies and tools for conversion into information, information into knowledge, and knowledge into plans forming that the drivers of profitable business. Business Intelligence includes data warehousing, business analysis tools, and knowledge management." This concept sees BI as a process by which this data is actually information that can be further converted into knowledge to ensure profitability. Sabherwal [21] defines BI as providing decision-makers with valuable information and knowledge by leveraging a variety of sources of data as well as structured and unstructured information.

\section{THE COMPONENTS OF BI}

Main elements of the BI are pronounced in the word investigation since the existence and co-operation of these components is essential to companies that actually take advantage of the benefits. The components are the following [23]: data mining; source of data; data warehousing; data visualization; decision support; Online Analytical Processing (OLAP). 
Data source is called source data warehousing that a variety of sources, the system may come from within the company [6]. We distinguish between internal data, which are formed within the organization and external data. The external data source may be economic environment, competitors or data on clients [6]. The BI concept is often used in conjunction with the data warehouse [2] concept, which is subject-oriented, integrated, data historicity storage, durable system whose main objective is to provide efficient information extraction of the data, in particular to support the decision-making process. The BI is an important component as well as the data visualization [16], which of those technologies is the common name, enabling the presentation of data and in some cases additional information was obtained in the data even according to their interpretation also some sub-processes in the data processing.

Effective knowledge mining, in order to gain advantages in a large amount of business -data found within an organization or from other sources of data mining [22]. OLAP [7], a software technology that enables analysts, businessmen and managers to company information organized according to dimensions assess compliance levels for rapid, consistent and interactive way. The one profession BI decision support [2], which is a combination of model-based data processing and decision-making processes that help managers decision-making activities.

\section{ADVANTAGES AND PROBLEMS ARISING FROM THE INTRODUCTION OF BI SYSTEMS}

Businesses decide to use a system because it benefits from the operation of a business acquisition and positive impact on the company 's progress on waiting for it. Otherwise it is not for the BI. The BI application offers many benefits to the employing organization, since the data is forging business advantage. Such advantages may include [20]:

- Data consistency check: BI applications can test the correctness, consistency of the data. The consistency of a database refers to the relationship between the number of data, where the content of a data element occurrences of the same as that of another of the same occurrence.

- Reduction of data redundancy: By redundancy we mean a data store more than one place in a database. It is difficult to avoid redundancy does not occur, but multiple occurrences to minimize any case an important goal. This can be an important tool for BI systems [24].

- Fast and robust decision-making: Through the BI decision makers of companies from a variety of business areas to look through the detailed and updated analysis due to which their decisions can help immediately and established facts may be taken.

- Access Faster Information: BI applications allow the necessary information there and then they have access to the users when and where you are need it. This will ensure fast and efficient information management.

- Making Effective Predictions: Based on the companies collected historical data, future environmental characteristics make an effective and reliable forecasts based on some estimated values.
- Improved internal communication: Enables organizations from within the enterprise more efficient communication, as it not only makes available the key users of the data.

- Improved data security: By achieving organizational data from a single portal is made, which is protected by the business - intelligence data security passwords properly treated.

- Exceptions Exploration: Includes corporate fraud, claims to detect. The significant advantage of some BI applications to existing applications and in business rules effectively combines the intelligent statistical forecasting models, and these together with the use of fraud detection.

- Reduced costs: for example, the drop in labor costs, costs of the time needed (eg, lower IT operating costs) and the costs of manual processing of any mistake by restoring the BI application.

- Involvement of mobile devices: gate opens towards you using BI to mobile devices with the involvement of staff from the office is able to carry out their duties.

- Handling of larger amounts of data: A massive amount of enterprise BI solutions for data collection, analysis and management can do.

- Increased profits: Businesses can gain more profits due to the BI technology, as these applications provide for them to receive relevant information about the service and reap the benefits derived from their customers and the market as a profitable investment before acquiring their competitors [14].

- More accurate stock records: BI software inventory monitoring of assisting companies in providing the right amount of stock available to push when the customer needs it and not let the company build up inventory.

- Revealing Hidden Business Rules: The BI system business strategies, the company is known and viewing of hidden rules for development and change management [9].

- To achieve more relevant information to BI applications more access to information about new learning opportunities, idea, services and products. It will also help the company to choose its own leaders. In addition, the reliable and timely information to help businesses make the right information to make informed decisions. This information may include any topic, such as agriculture, fisheries, land, education, vocational skills, livelihood, economy, etc.

- Customer needs, behaviour understanding and reaching a wider customer base: BI applications collect information on customers and clients. So businesses can learn about their customers' needs, adapt to their needs. Learn about current and future customer's habits and build up a wider range of customers. 
- Exploring patterns of behaviour: The behavioral economics of the economic behavior of individuals engaged in the researching drivers of individual decisions and actions. Revealed by behavioral economics are different rules often assumed by neoclassical economics, behavioral rules. It is not yet clear to what extent compatible with these different sets of rules, such that it is not completely clear how revealed by behavioral economics behavioral patterns affect social outcomes, ie. what effect on the aggregate level [8].

BI projects often face obstacles during construction. The reasons are many. Based on Santané et al [6], the following factors can be traced to the failure of any BI project. (1)The project does not receive the necessary business support. (2) The project members are not sufficiently skilled and/or are not available; sometimes its participants can not be used for certain tasks properly. (3) The project participants are not willing to participate actively in the tasks. (4) Not enough attention is paid to issues related to data quality (not taken into account the effect of the poor quality of data in business profitability). (5) Not used in software development methodology. (6) Improper handling, use of metadata. Metadata is "data about data" [19]. (7) Is the organization aware that a BI project, the department spanning initiative so different from the independent solutions used previously. (8) You can not perform business analysis. (9) No work breakdown structure. (10) Too insisting on a specific methodology or tool.

\section{THE RESEARCH METHOD}

Examination of the characteristics of the research is to use BI applications operating in the Hungarian enterprises. The research has been carried out by a questionnaire. The questionnaires were sent out to businesses randomly, regardless of company size, activity and geographical location. The filling questionnaire of a sample is not representative, so the results of the investigation only interpreted the scope of companies involved in the research.

\section{A. The objectives of the research}

The primary objective of the research is examining the experiences of BI applications among Hungarian enterprises. The research aims to

1) Uncover the basis of the responses received from the first questionnaire to a different company sizes are expected to benefit from the business use of BI systems,

2) Companies to perform tasks that used for BI applications

3) Success or failure of the third company size varies by whether the use of BI.

Among the objectives included assessment of the future use of BI technologies, taking into account the categories of enterprises, and in the investigation as to how the business of the opinion that it should develop a greater proliferation of BI systems.

\section{B. The research assumptions}

The first step of the research assumed examines the benefits of using the BI enterprise size. In this connection, the following assumptions were made.

1) Category in different advantages in the use of BI.

2) It is more common for corporations and medium-sized enterprises in the positive experience than small businesses in connection with the operation of BI applications. (a) Perform different size categories of tasks used in BI applications. (b) Areas of successful BI applications using the different enterprise size. (c) Using the areas of BI applications unsuccessful vary by enterprise size.

3) Size categories are different opinions about how it should develop BI applications.

\section{The model features}

The questionnaire was filled out by 77 pieces of Hungarian enterprises in 2013. Examining the binding of the companies that completed size concluded that the sample represent themselves in a similar proportion of micro, small and medium-sized enterprises and large corporations.
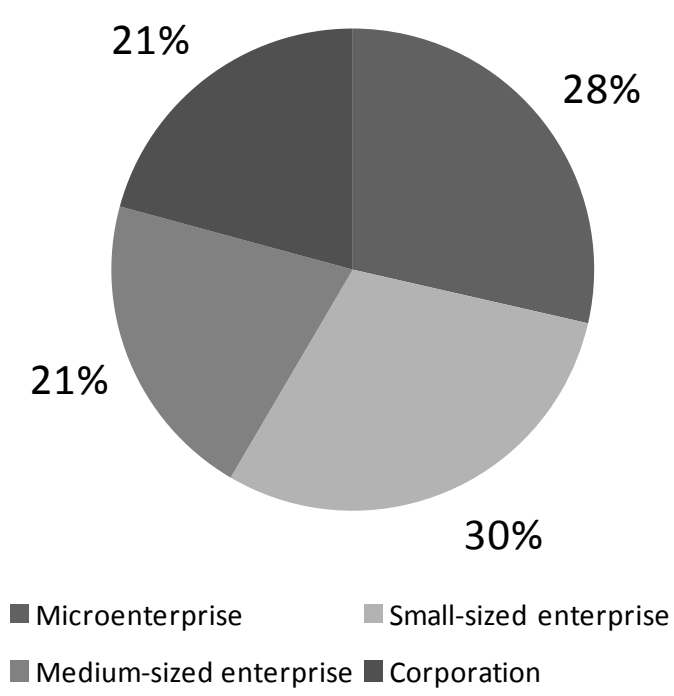

Fig. 1. The distribution of respondents by size categories

Less than one tenth of the respondents said that they work in the enterprise BI system or application. The studied companies are large companies have most BI applications, small and medium-sized enterprises is almost the same percentage, while the micro-enterprises are not used at all. Determining the proportion of those firms that do not operate the system and no plans to introduce them. 


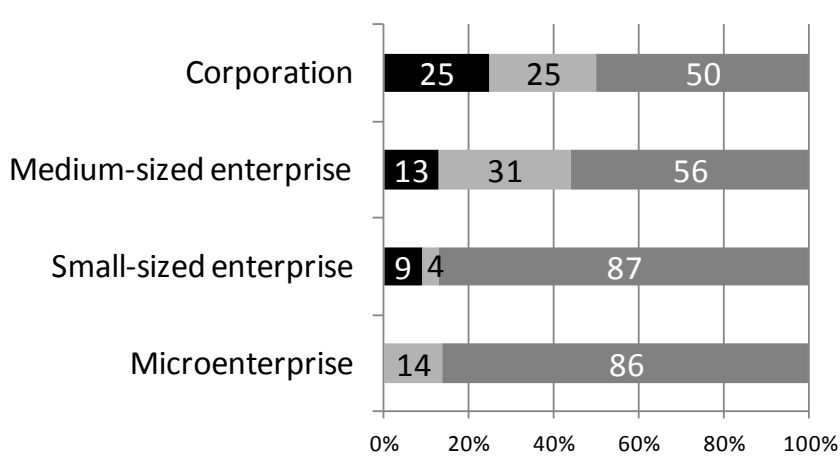

It operates

It does not operate but its introduction is planned

- It does not operate and its introduction is not planned

Fig. 2. The application of BI systems in Hungary by company size categories in 2013

\section{THE FREQUENCY OF BI APPLICATIONS AMONG THE HUNGARIAN ENTERPRISES}

According to IDC [11] in 2011 to assess the Hungarian BI applications market growth characteristics. An interesting result of the study, despite occurring in 2008, the global economic crisis in 2009 increased by $14.7 \%$ in the Hungarian BI market size. In the coming years, the market also increased, but to a lesser extent. The 2011 analysis predicts that in 2013, an increase of $7 \%$ will be [10]. A significant part of the query and analytics market makes up the other part is made up of advanced analytical applications [24].

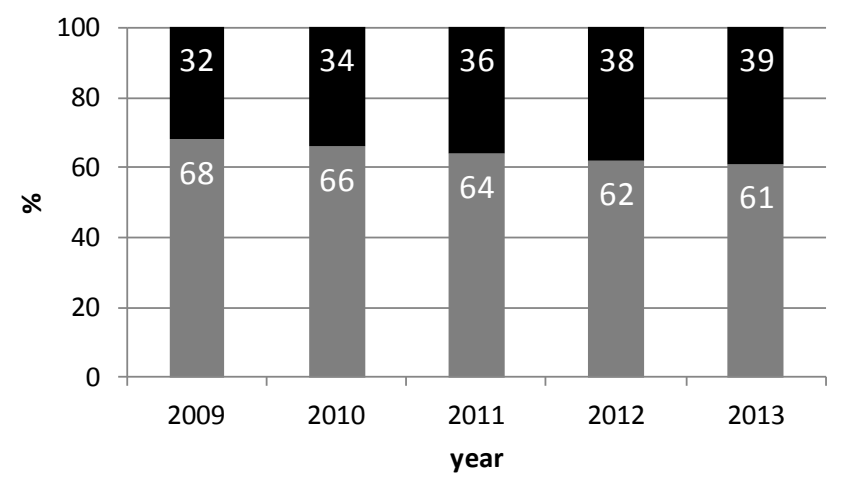

Query, reporting, analytics Advanced analytical applications

Fig. 3. Changes in the size of the Hungarian Business Intelligence market

Based on the survey of the Hungarian small and mediumsized enterprises hardly, while micro enterprises did not apply the BI applications in their activities. The large companies surveyed only one fifth to one tenth of the small and mediumsized businesses have been in possession of a BI application, but all three major categories of businesses, the percentage of people who do not plan to use these systems in the future [23].

\section{A. Expected advantages of using BI systems}

The companies aim to provide your company service systems are set to benefit from the use. Advantage, which may be more favorable position in the market over their competitors. The company size categories, each handling a larger amount of data clearly waiting for BI applications [19]. The use of hypothetical positive effect also seen as a quicker access to information, improved and more accurate inventory records of internal communications.

TABLE I. EXPECTED ADVANTAGES OF USING BI SySTEMS IN HUNGARY BY SIZE CATEGORIES IN HUNGARY IN 2013

\begin{tabular}{|l|r|r|r|r|}
\hline \multicolumn{1}{|c|}{ Activity } & $\begin{array}{c}\text { Micro- } \\
\text { enterprise } \\
\text { /ranking/ }\end{array}$ & $\begin{array}{c}\text { Small-sized } \\
\text { enterprise } \\
\text { /ranking/ }\end{array}$ & $\begin{array}{c}\text { Medium-sized } \\
\text { enterprise } \\
\text { /ranking/ }\end{array}$ & $\begin{array}{c}\text { Corpo- } \\
\text { ration } \\
\text { /ranking/ }\end{array}$ \\
\hline $\begin{array}{l}\text { Handling greater } \\
\text { amount of data }\end{array}$ & $1(64 \%)$ & $1(83 \%)$ & $1(75 \%)$ & $1(69 \%)$ \\
\hline $\begin{array}{l}\text { Faster access to } \\
\text { information }\end{array}$ & $2(59 \%)$ & $2(57 \%)$ & $3(44 \%)$ & $2(56 \%)$ \\
\hline $\begin{array}{l}\text { More appropriate } \\
\text { inventory }\end{array}$ & $3(50 \%)$ & $5(48 \%)$ & $2(56 \%)$ & $6(25 \%)$ \\
\hline Forecasting & $4(41 \%)$ & $3(52 \%)$ & $7(31 \%)$ & $3(50 \%)$ \\
\hline $\begin{array}{l}\text { Improved internal } \\
\text { communication }\end{array}$ & $6(41 \%)$ & $4(52 \%)$ & $4(44 \%)$ & $4(44 \%)$ \\
\hline $\begin{array}{l}\text { Access to a } \\
\text { broader range of } \\
\text { customers }\end{array}$ & $5(41 \%)$ & $7(22 \%)$ & $5(38 \%)$ & $7(25 \%)$ \\
\hline $\begin{array}{l}\text { Access to more } \\
\text { relevant } \\
\text { information }\end{array}$ & $7(36 \%)$ & $6(26 \%)$ & $8(31 \%)$ & $5(31 \%)$ \\
\hline $\begin{array}{l}\text { Data consistency } \\
\text { control }\end{array}$ & $9(18 \%)$ & $9(17 \%)$ & $6(38 \%)$ & $8(25 \%)$ \\
\hline $\begin{array}{l}\text { Better ability to } \\
\text { adaptation }\end{array}$ & $10(14 \%)$ & $10(13 \%)$ & $9(25 \%)$ & $11(13 \%)$ \\
\hline Higher profits & $13(9 \%)$ & $8(22 \%)$ & $12(13 \%)$ & $10(25 \%)$ \\
\hline $\begin{array}{l}\text { Reducing } \\
\text { redundant data }\end{array}$ & $8(32 \%)$ & $13(9 \%)$ & $11(19 \%)$ & $12(13 \%)$ \\
\hline $\begin{array}{l}\text { Inclusion of } \\
\text { mobile devices }\end{array}$ & $14(9 \%)$ & $12(13 \%)$ & $10(25 \%)$ & $9(25 \%)$ \\
\hline $\begin{array}{l}\text { Lower IT } \\
\text { operation costs }\end{array}$ & $12(9 \%)$ & $11(13 \%)$ & $13(6 \%)$ & $13(13 \%)$ \\
\hline $\begin{array}{l}\text { Revealing } \\
\text { exceptions }\end{array}$ & $11(9 \%)$ & $14(9 \%)$ & $14(6 \%)$ & $14(13 \%)$ \\
\hline $\begin{array}{l}\text { Revealing hidden } \\
\text { business rules }\end{array}$ & $15(5 \%)$ & $16(0 \%)$ & $15(6 \%)$ & $15(13 \%)$ \\
\hline $\begin{array}{l}\text { Revealing } \\
\text { behavioural } \\
\text { patterns }\end{array}$ & $16(5 \%)$ & $15(9 \%)$ & $16(0 \%)$ & $16(6 \%)$ \\
\hline
\end{tabular}

Separately examining the size in the responses it can be seen that each of the four categories of handling large amounts of data response options marked the biggest percentage. In the case of micro and small enterprises and large corporations in second place for faster access to information is to be considered the benefits of BI, while medium-sized enterprises by analyzing the responses of more accurate inventory records occupies this space. Microenterprises in terms of more accurate set of records in third place. Improvement of internal communication for small and medium-sized enterprises classified in this position, the order of the projections of large and small businesses. The medium-sized enterprises percent of responses came from the same access to information faster response option such as communications improve. On completion of the chi- square test the result available to no one answers are significantly related to company size. Businesses of all sizes benefit from the same category BI application of the first three places are implied. So we can conclude that 
company size has no effect on what the company expects to benefit from business intelligence applications.

\section{B. Experiences gained on using BI systems in Hungary}

BI applications are used to perform certain tasks in the organization, in order to speed up, facilitate and simplify work processes. Using BI in the enterprise may experience both positive and negative. This part of the research of microenterprises are not included, as they have stated they do not use BI systems so they could get no experience.

TABLE II. EXPERIENCES GAINED ON USING BI SYSTEMS IN HUNGARY BY SiZE CATEGORIES IN 2013

\begin{tabular}{|l|r|r|r|}
\hline & $\begin{array}{c}\text { Small-sized } \\
\text { enterpises }\end{array}$ & $\begin{array}{c}\text { Medium-sized } \\
\text { enterprises }\end{array}$ & Corporations \\
\hline All successful & $6 \%$ & $0 \%$ & $0 \%$ \\
\hline Rather successful & $56 \%$ & $75 \%$ & $85 \%$ \\
\hline Rather unsuccessful & $0 \%$ & $0 \%$ & $0 \%$ \\
\hline All unsuccessful & $0 \%$ & $0 \%$ & $0 \%$ \\
\hline No such projects & $38 \%$ & $25 \%$ & $15 \%$ \\
\hline
\end{tabular}

Small businesses are $38 \%$ and $25 \%$ of medium-sized and corporations $15 \%$ of said that there was no organization either of these projects. That all experiences have been successful only on small companies arrived by a marginal response. Among the respondents "rather successful" response option was the most common, as all the three categories identified a significant proportion of this option. $56 \%$ of small businesses, medium-sized companies and three -quarters the size of the largest $85 \%$ of the company deems more successful BI functionality. The reason may be that the larger the business the more favorable economic situation, which allows input of larger amounts of the BI field. Qualified professionals and consultants can apply the right skills who are able to derive a BI project, thereby increasing the chances of successful implementation and use.

\section{1) Activities performed by BI systems}

Based on the responses received, it can be said that small and medium-sized businesses in the first place to carry out financial analysis applied to the BI tools in large companies, however, a striking degree of strategic decision-making. The company size secondly, market analysis, preparing and controlling the field are turning to BI support. The results of the study are summarized in the table below.

TABLE III. ACtivities PeRformed by BI Systems In Hungary by Size CATEGORIES IN 2013

\begin{tabular}{|c|c|c|c|c|c|c|}
\hline \multirow{2}{*}{ Activity } & \multicolumn{2}{|c|}{$\begin{array}{l}\text { Small-sized } \\
\text { enterprises }\end{array}$} & \multicolumn{2}{|c|}{$\begin{array}{l}\text { Medium-sized } \\
\text { enterprises }\end{array}$} & \multicolumn{2}{|c|}{ Corporations } \\
\hline & score & $\begin{array}{l}\text { ran- } \\
\text { king }\end{array}$ & score & $\begin{array}{l}\text { ran- } \\
\text { king }\end{array}$ & score & $\begin{array}{l}\text { ran- } \\
\text { king }\end{array}$ \\
\hline Financial analysis & 3.56 & 1 & 4.42 & 1 & 392 & 1 \\
\hline Controlling & 3.44 & 2 & 4.08 & 2 & 3.92 & 2 \\
\hline Market analysis & 3.18 & 3 & 3.83 & 3 & 3.23 & 5 \\
\hline $\begin{array}{l}\text { Strategic decision- } \\
\text { making }\end{array}$ & 2.71 & 10 & 3.67 & 4 & 3.69 & 3 \\
\hline Forecasting & 3.06 & 5 & 2.83 & 10 & 3.38 & 4 \\
\hline $\begin{array}{l}\text { Optimization of } \\
\text { transaction processes }\end{array}$ & 3.00 & 6 & 3.33 & 7 & 2.92 & 6 \\
\hline
\end{tabular}

\begin{tabular}{|l||r|r||r|r||r|r|}
\hline Risk analysis & 2.94 & 7 & 3.50 & 6 & 2.77 & 7 \\
\hline $\begin{array}{l}\text { Product } \\
\text { development }\end{array}$ & 3.12 & 4 & 3.50 & 5 & 2.54 & 9 \\
\hline $\begin{array}{l}\text { Customer } \\
\text { relationship } \\
\text { management }\end{array}$ & 2.76 & 9 & 2.92 & 9 & 2.62 & 8 \\
\hline Activity monitoring & 2.88 & 8 & 3.33 & 8 & 2.31 & 10 \\
\hline
\end{tabular}

Performing the chi-square test showed no significant correlation with either case of company sizes.

\section{2) Areas of the successful use of BI systems}

Answering the survey questions for small businesses, according to the BI applications were in the field of financial analysis and market analysis are the most successful, and controlling, but also in relation to customer management success in the BI system. The medium-sized enterprises in particular have experienced success in controlling and monitoring activity. The second place in their case, the financial analysis, preparation of forecasts, market analysis and customer management replaced, and the third strategic decision-making. Set up by the big companies in the following order: financial analysis, controlling, strategic decisionmaking. The answers to the business as a whole experienced a case of risk analysis and product development in the least that the BI system would be successful.

TABLE IV. EXPERIENCES ON THE SUCCESSFUL IMPLEMENTATION OF BI SYSTEMS IN HUNGARY BY SIZE CATEGORIES IN HUNGARY IN 2013

\begin{tabular}{|l||r|r||r|r||r|r|}
\hline \multirow{2}{*}{\multicolumn{1}{|c||}{ Activity }} & \multicolumn{2}{c||}{$\begin{array}{c}\text { Small-sized } \\
\text { enterprises }\end{array}$} & \multicolumn{2}{c|}{$\begin{array}{c}\text { Medium-sized } \\
\text { enterprises }\end{array}$} & \multicolumn{2}{c|}{ Corporations } \\
\cline { 2 - 7 } & $\begin{array}{c}\text { fre- } \\
\text { quency }\end{array}$ & $\begin{array}{r}\text { ran- } \\
\text { king }\end{array}$ & $\begin{array}{c}\text { fre- } \\
\text { quency }\end{array}$ & $\begin{array}{r}\text { ran- } \\
\text { king }\end{array}$ & $\begin{array}{r}\text { fre- } \\
\text { quency }\end{array}$ & $\begin{array}{r}\text { ran- } \\
\text { king }\end{array}$ \\
\hline Financial analysis & $26 \%$ & 1 & $25 \%$ & 3 & $56 \%$ & 1 \\
\hline Controlling & $17 \%$ & 3 & $31 \%$ & 1 & $50 \%$ & 2 \\
\hline Market analysis & $26 \%$ & 2 & $25 \%$ & 4 & $25 \%$ & 4 \\
\hline $\begin{array}{l}\text { Activity } \\
\text { monitoring }\end{array}$ & $9 \%$ & 6 & $31 \%$ & 2 & $6 \%$ & 9 \\
\hline $\begin{array}{l}\text { Customer } \\
\text { relationship } \\
\text { management }\end{array}$ & $13 \%$ & 5 & $25 \%$ & 6 & $19 \%$ & 6 \\
\hline Forecasting & $17 \%$ & 4 & $25 \%$ & 5 & $25 \%$ & 5 \\
\hline $\begin{array}{l}\text { Optimization of } \\
\text { transaction } \\
\text { processes }\end{array}$ & $9 \%$ & 7 & $13 \%$ & 8 & $13 \%$ & 7 \\
\hline $\begin{array}{l}\text { Strategic } \\
\text { decision-making }\end{array}$ & $4 \%$ & 9 & $19 \%$ & 7 & $31 \%$ & 3 \\
\hline Risk analysis & $0 \%$ & 10 & $0 \%$ & 10 & $13 \%$ & 8 \\
\hline $\begin{array}{l}\text { Product } \\
\text { development }\end{array}$ & $9 \%$ & 8 & $6 \%$ & 9 & $6 \%$ & 10 \\
\hline
\end{tabular}

The related false assumption, since cross-tabulations by running test can not be said that the company size affect the performance of certain tasks BI systems success.

\section{3) Areas of unsuccessful use of BI systems}

Examination of the experience gained in the use of BI systems in the study continued to fail in what were most of these applications, and this is in the context of company size if they fail to reach an area of BI. 
Among the small businesses in the strategic decisionmaking was the least successful of BI systems. The mediumsized enterprises stated that they experienced the most failures in the field of risk analysis, and forecasts for the major companies. Based on the responses of the enterprises controlling the performance of the tasks was the least typical BI fails.

TABLE V. EXPERIENCES ON THE UNSUCCESSFUL IMPLEMENTATION OF BI SYSTEMS IN HUNGARY BY SIZE CATEGORIES IN HUNGARY IN 2013

\begin{tabular}{|l||l|l||l|l||l|l|l|}
\hline \multirow{2}{*}{\multicolumn{1}{|c||}{ Activity }} & \multicolumn{2}{c||}{$\begin{array}{c}\text { Small-sized } \\
\text { enterprises }\end{array}$} & \multicolumn{2}{c|}{$\begin{array}{c}\text { Medium-sized } \\
\text { enterprises }\end{array}$} & \multicolumn{2}{c|}{ Corporations } \\
\cline { 2 - 5 } & $\begin{array}{c}\text { fre- } \\
\text { quency }\end{array}$ & $\begin{array}{c}\text { ran- } \\
\text { king }\end{array}$ & $\begin{array}{c}\text { fre- } \\
\text { quency }\end{array}$ & $\begin{array}{c}\text { ran- } \\
\text { king }\end{array}$ & $\begin{array}{c}\text { fre- } \\
\text { quency }\end{array}$ & $\begin{array}{c}\text { ran- } \\
\text { king }\end{array}$ \\
\hline Forecasting & $9 \%$ & 6 & $13 \%$ & 5 & $31 \%$ & 1 \\
\hline $\begin{array}{l}\text { Optimization of } \\
\text { transaction } \\
\text { processes }\end{array}$ & $9 \%$ & 5 & $19 \%$ & 2 & $6 \%$ & 6 \\
\hline $\begin{array}{l}\text { Product } \\
\text { development }\end{array}$ & $4 \%$ & 7 & $6 \%$ & 8 & $19 \%$ & 3 \\
\hline Risk analysis & $13 \%$ & 2 & $25 \%$ & 1 & $0 \%$ & 9 \\
\hline $\begin{array}{l}\text { Unsuccessful } \\
\text { introduction of } \\
\text { applications }\end{array}$ & $13 \%$ & 4 & $13 \%$ & 4 & $13 \%$ & 5 \\
\hline Market analysis & $0 \%$ & 11 & $19 \%$ & 3 & $19 \%$ & 2 \\
\hline $\begin{array}{l}\text { Customer } \\
\text { relationship } \\
\text { management }\end{array}$ & $4 \%$ & 9 & $6 \%$ & 10 & $19 \%$ & 4 \\
\hline $\begin{array}{l}\text { Strategic } \\
\text { decision-making }\end{array}$ & $22 \%$ & 1 & $0 \%$ & 11 & $0 \%$ & 11 \\
\hline $\begin{array}{l}\text { Unsuccessful } \\
\text { development } \\
\text { project }\end{array}$ & $13 \%$ & 3 & $6 \%$ & 7 & $6 \%$ & 8 \\
\hline $\begin{array}{l}\text { Activity } \\
\text { monitoring }\end{array}$ & $4 \%$ & 8 & $6 \%$ & 9 & $0 \%$ & 10 \\
\hline $\begin{array}{l}\text { Financial } \\
\text { analysis }\end{array}$ & $0 \%$ & 12 & $13 \%$ & 6 & $6 \%$ & 7 \\
\hline Controlling & $4 \%$ & 10 & $0 \%$ & 12 & $0 \%$ & 12 \\
\hline
\end{tabular}

The assumption is that company size affects the BI fail to fulfill the various tasks. Examining the adequacy of the established claim in case of failure occurring in the strategic decision-making in a significant relationship between the size of the business. The smaller the business is, the more experience there is the BI system failure in carrying out this task.

\section{The future use of BI systems in Hungary}

The ever-accelerating world of BI tools, the use of technology becomes a necessity for businesses. Half of small business and large corporations believe that the spread of BI systems to help reduce costs the most. Small businesses are $65 \%$, while $56 \%$ of medium-sized businesses have the same view. The Hungarian companies are reluctant to spend higher amounts on BI systems, which introduce the size of the enterprise, the IT sector and related developmental depending on several million forints can range from 20 to 30 million forints (Kövesdi 2011). Secondly, the survey respondents criticized the level of protection of BI applications, as the respondent medium-sized businesses and large enterprises, $38 \%$ of them considered that the data protection should be repaired to ensure a higher level. Micro and small-sized enterprises with more than $20 \%$ think the same way. The existence of a simple parameter setting is considered to be the predominant BI roll-out of business. A medium-sized businesses for over $40 \%$ believe that the parameterisation simplify support the advancement of BI applications, microbusinesses and large enterprises and $20 \%$, while $26 \%$ of small business takes the same view. Corporations according to the manufacturer's independence and the greater spread of standard features also contribute to the spread of these systems.

TABLE VI. FACtors HELPING THE SPREAD OF BI SYSTEMS IN HUNGARY BY SIZE CATEGORIES IN 2013

\begin{tabular}{|l|r|r|r|r|}
\hline \multicolumn{1}{|c|}{ Activity } & \multicolumn{1}{|c|}{$\begin{array}{c}\text { Micro- } \\
\text { enterprises } \\
\text { /ranking/ }\end{array}$} & $\begin{array}{c}\text { Small-sized } \\
\text { enterprises } \\
\text { /ranking/ }\end{array}$ & $\begin{array}{c}\text { Medium- } \\
\text { sized } \\
\text { enterprises } \\
\text { /ranking/ }\end{array}$ & $\begin{array}{c}\text { Cor- } \\
\text { porations } \\
\text { /ranking/ }\end{array}$ \\
\hline Cost reduction & $1(50 \%)$ & $1(65 \%)$ & $1(56 \%)$ & $1(50 \%)$ \\
\hline $\begin{array}{l}\text { Higher level } \\
\text { of data } \\
\text { protection }\end{array}$ & $2(27 \%)$ & $3(22 \%)$ & $3(38 \%)$ & $2(38 \%)$ \\
\hline $\begin{array}{l}\text { Simpler para- } \\
\text { meterizing }\end{array}$ & $3(18 \%)$ & $2(26 \%)$ & $2(44 \%)$ & $5(19 \%)$ \\
\hline $\begin{array}{l}\text { Higher } \\
\text { independence } \\
\text { from manu- } \\
\text { facturers }\end{array}$ & $4(14 \%)$ & $5(9 \%)$ & $4(25 \%)$ & $3(25 \%)$ \\
\hline $\begin{array}{l}\text { Extended } \\
\text { standard } \\
\text { functions }\end{array}$ & $5(14 \%)$ & $4(13 \%)$ & $6(13 \%)$ & $4(25 \%)$ \\
\hline $\begin{array}{l}\text { Better automa- } \\
\text { tization of data } \\
\text { integration }\end{array}$ & $6(0 \%)$ & $6(9 \%)$ & $5(19 \%)$ & $6(13 \%)$ \\
\hline
\end{tabular}

The assumption - that are the same size category as the opinions about how it should develop business intelligence applications - has become reasonably the results obtained, the opinion of the show business conform to the test aspects.

\section{CONCLUSION}

The research aims to present and analyze the application of BI Hungarian experiences among enterprise. The paper intends to find answers to the following questions:

1) Companies to manage most of the larger amount of data for faster access to information and the provision of accurate stock records see the benefits of BI. The expected benefits of independent evolution of the size of the company.

2) Major Hungarian companies and medium-sized enterprises frequent positive experiences, such as small enterprises in the use of $B I$, as a result of the analysis indicate that the larger the firm, the more positive experiences have enjoyed the use of the BI. (a) Businesses most of the risk analysis, financial analysis, market analysis and controlling field is applied to BI applications. They do this regardless of méretkategóriától. (b) The most important areas of successful BI use of financial analysis, market analysis and controlling independently from size categories. (c) To fail in the most important areas of BI Making use of the predictions, the introduction and application of risk analysis. Significant relationship between company size can be observed in the area of strategic decision-making. 
3) Businesses to reduce costs, higher levels of data protection and simple parameterization is considered so that could be the key to the spread of BI systems. REFERENCES

[1] A. Gábor, "Üzleti informatika", AULA Kiadó, Budapest, 2007

[2] A. Jánosa, "Üzleti intelligencia alkalmazások", ComputerBooks Kiadó, Budapest, 2010.

[3] B. Marr, "What is Business Intelligence (BI)?", Advanced Performance Institute In: http://www.ap-institute.com/Business\%20Intelligence.html

[4] D. Loshin, "Business Intelligence: The Savvy Manager's Guide", Newnes, 2012.

[5] D. R. Szabó "Kockázatelemző szoftverek összehasonlító elemzése", in Kovács Norbert, Építőkockák. 199 p. Győr: Universitas-Győr Nonprofit Kft., pp. 113-136. 2014

[6] E. Sántáné- Tóth, M. Bíró, A. Gábor, A. Kő and L. Lovrics, "Döntéstámogató rendszerek", Panem Könvkiadó, Budapest, 2008

[7] E.F. Codd, S.B Codd, and C.T. Salley, "Providing OLAP (On-line Analytical Processing) to User-Analysts: An IT Mandate, Codd \& Date", 1993.

[8] G. Koltay and J.Vincze J. "Fogyasztói döntések a viselkedési közgazdaságtan szemszögéből", Közgazdasági Szemle, LVI. évf., 2009. június, 495-525. o.

[9] I. Graham "Business Rules Management and Service Oriented Architecture: A Pattern Language", Wiley, 2007, ISBN 9780470027219

[10] "IKT helyzetelemzés 2010 végén", 2011 - See more at: http://einclusion.hu/2011-01-27/ikt-helyzetelemzes-2010-vegen/

[11] "International Data Corporation (IDC)" - See more at: http://idchungary.hu/hun/about-idc/company-overview

[12] J. Szabó "Adatokból üzleti előny? Az üzleti intelligencia alkalmazások tapasztalatai a magyarországi vállalkozások körében", Miskolci Egyetem, TDK-dolgozat, 2013.

[13] L. Cser, B. Fajszi, T. Fehér, "Üzleti haszon az adatok mélyén, Az adatbányászat mindennapjai", Alinea Kiadó, 2010.
[14] L. James, "Top 14 Benefits of Business Intelligence", - See more at: http://smartdatacollective.com/yellowfin/42423/yellowfin-top-14benefits-business-intelligence-part-one

[15] M. Aranyossy, A. Nemeslaki and A. Fekó, "Empirical Analyis of Public ICT Development Project Objectives in Hungary" International Journal of Advanced Computer Science and Applications (IJACSA), 5(12), 2014. http://dx.doi.org/10.14569/IJACSA.2014.051206 - See more at: http://thesai.org/Publications/ViewPaper?Volume $=5 \&$ Issue $=12 \&$ Code $=I$ JACSA\&SerialNo=6\#sthash.CQYfHNXW.dpuf

[16] M. Friendly, "Milestones in the history of thematic cartography, statistical graphics, and data visualization", 2008 - See more at: http://www.math.yorku.ca/SCS/Gallery/milestone/milestone.pdf

[17] M. Gibson, D. Arnott, I. Jagielska and A. Melbourne, "Evaluating the Intangible Benefits of Business Intelligence", Review \& Research Agenda, Proceedings of the 2004 IFIP International Conference on Decision Support Systems (DSS2004): Decision Support in an Uncertain and Complex World, pp. 295-305. 2004

[18] NISO, "Understanding Metadata", NISO Press. ISBN 1-880124-62-9. Retrieved 5 January 2010.

[19] P. Sasvári, "Az üzleti információs rendszerek használatának jellemzői a magyarorzági és ausztriai kis- és középvállalkozások körében", 2013, See more at:: http://www.irisro.org/gazdasagtan2013januar/G436SasvariPeter.pdf

[20] R. Bellu, "Microsoft Dynamics GP", Wiley, John \& Sons, Incorporated, 2008.

[21] R. Sabherwal, "Succeding with Business Intelligence: Some Insights and Recommendations" Cutter Benchmark Review, 7 (9): 5-15, 2007.

[22] U. Fayyad, G. Piatetsky-Shapiro, P. Smyth, "From Data Mining to Knowledge Discovery in Databases", American Association for Artificial Intelligence, 1996.

[23] W. W. Eckerson, "Extending the Value of Your Data Warehousing Investment", The Data Warehousing Institute - See more at: http://tdwi.org/Articles/2007/05/10/Predictive-Analytics.aspx?Page=2, 2010.

[24] Z. Kövesdi "Üzleti intelligencia megoldások a vállalkozásoknál", Infotér elemzés, 2011. 